\title{
スパイラルダクトの分肢損失実験 (片コーン型直角分岐管の場合)
}

正会員 ○井上嘉 雄*

緒 言 直角分岐管の内, コーン型を用いると局部抵 抗損失 $\zeta_{b}$ が半減すると言われているが，分岐部の流れ の形態より考えて，本実験に示す片コーン型值角分岐管 の方が更に性能が良いと考えられるので数種の片コーン 型直角分岐管を新作し，その性能を比較した。

実験概要 スパイラルダクト，本管 $\phi 150 \mathrm{~mm}$ に分㥏 管 $\phi 75 \mathrm{~mm}$ を片コーン型直角分岐管 8 種類と直角分岐 管 1 種類とで接合してみ，その分岐抵抗損垁を実測し た。支管分流抵抗 $\zeta_{b}$ は分岐点に集中するものと仮定 し，上流側動圧を基準として計算した。実験供試体は図 一1に示すもので，亜鉛鉄板製である。A，B，C，D は 分岐長さ $Y$ を一定として角度いを变化させたものであ る。 $\mathrm{E}, \mathrm{F}, \mathrm{G}, \mathrm{H}$ は $X$ を一定 (150 mm, 本管サイズと 同一）として $\beta$ を変化させて製作したものである。実験 装置は文献 3 と同一である。

実験結果 図一2 に今までに発表になっているいるい ろな觕度の普通の分岐管の理論式や実測結果を示す。片 コーン型直角分岐管は新考案なので本件に関する実験デ 一夕は見られない。図一3に本実験の支管分流抵抗 $\zeta_{b}$ のカーブを示す。図示の如く，ほぼ三つのグループに分
同大谷清喬林，同，太田則佳***

かれ，A，B，E，C が成績がよく，I，H， G は成續が覀 い。この結果を $\beta$ により比較すると $\beta$ が $60^{\circ} \sim 75^{\circ}$ のも のは良い結果であったが， $\beta$ が $60^{\circ}$ でも，Aと Fとでは 成績がうんとちがう事がわかる。これより及ばかりでな く $Y / X$ の值も関係する事が予想される。Y/X の值は 1.1〜1.83 までの值が良い結果を示している。るた図一 3 中の点線は文献 ${ }^{2)}$ の中にあるロングコーン型分岐管 $=70^{\circ}, Y / X=1.5$ の值である。片コーン型でこれに形が 似ているのはBとCとでともに風速比 $V_{b} / V_{u}$ が1.0より 大きい所では，かくだんに良い結果を示す。これより片 コーン型がコーン型より良い結果を示すと予想できる。

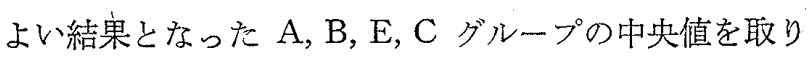
この場合（面積比 $M=4 ） の \zeta_{b}$ を示す公式を試算して 見ると， $\zeta_{b}=1.1\left(V_{b} / V_{u}-3.25\right)^{2}$ となる。

謝辞 実験機材提供の日本産業機械 $\mathrm{KK}$ に謝意を表す。

文献

1) C.M. Ashley 外: Branch Fittings Performance At High Velocity, ASHAE Transaction Vol. 62, 1956'

2）井上㔛雄：スパイラルダクトの分岐損失実験 日本建築 学会論文報告集第 89 号, 第 103 号。

3）文献 2) と同一題目，本学会関東支部研第 33 回

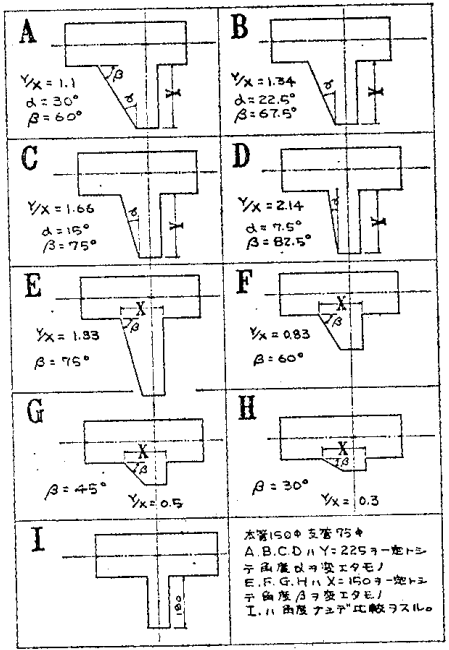

図-1 片コーン型直盾分忮管と直角分妓管

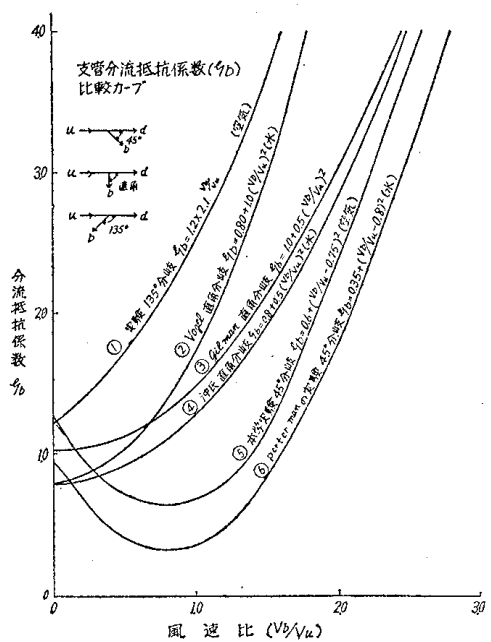

図一-2 支管分流抵抗 $\zeta_{b}$ のいろいる

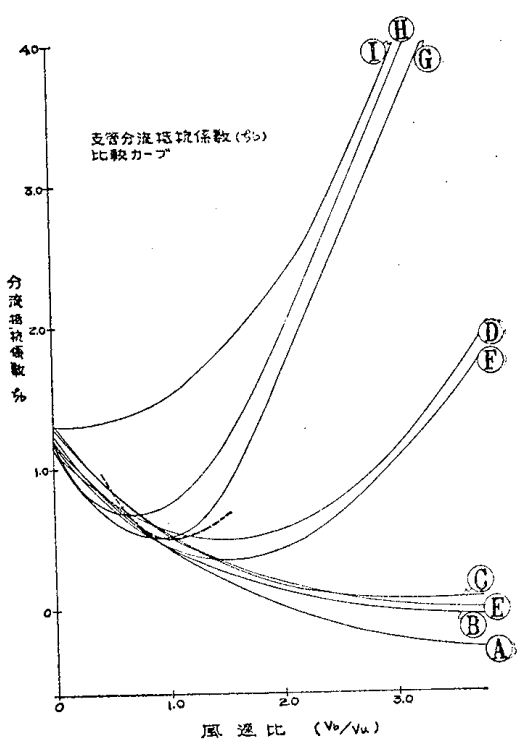

図-3

*關東学院大学助教授 $*^{* *}$ 松田平田設計事務所 $* * *$ 第一工業 $\mathrm{K} \mathrm{K}$ 